\title{
Trump nominee backs Paris climate agreement and questions Iran nuclear deal
}

\author{
But Rex Tillerson, Trump's pick for secretary of state, tells senators that efforts to predict climate change are 'very \\ limited'.
}

Jeff Tollefson

11 January 2017

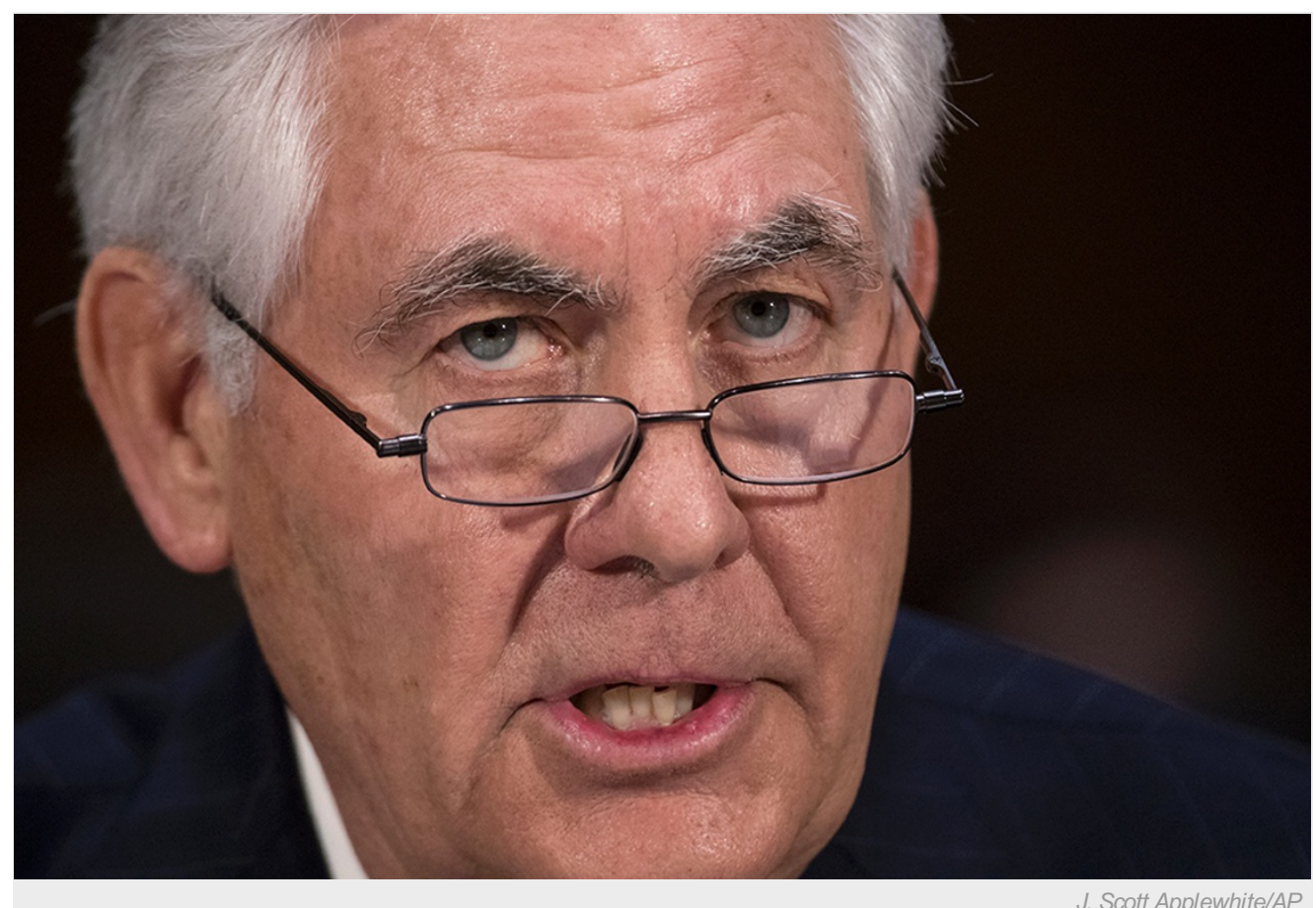

Rex Tillerson is the former chief executive of oil giant ExxonMobil.

Rex Tillerson, US president-elect Donald Trump's nominee for the post of secretary of state, says that the United States should remain part of the 2015 Paris climate agreement.

"It's important that the US maintain its seat at the table," Tillerson told the Senate Committee on Foreign Relations during his confirmation hearing on 11 January. The threat of global warming is real and "requires a global response", he added. "No one country is going to solve this on its own."

As the top US diplomat, Tillerson — who was chief executive of oil giant ExxonMobil until his nomination — would lead international climate negotiations for the Trump administration. He declined to discuss how his own positions conflict with those of Trump, who has questioned climate science and promised to pull the United States out of the Paris agreement.

Tillerson told senators that a carbon tax is the wisest way to reduce the greenhouse-gas emissions that drive global warming. But he stressed that the state department does not oversee domestic climate policy.

Tillerson baulked at questions about ExxonMobil's financial support of scientists and groups that deny climate science and oppose climate regulations, saying he could no longer speak on behalf of the company. When a Democratic senator asked whether Tillerson lacked the knowledge to respond or was just refusing to, Tillerson said "a little of both".

\section{In the hot seat}

When asked whether greenhouse-gas emissions from human activities cause climate change, Tillerson said that "the increase in greenhouse-gas concentrations in the atmosphere [is] having effect". But, he added, "our ability to predict that effect is very limited". 
Resources Institute, an environmental think tank in Washington DC. "Both Trump and Tillerson have wavered on climate science in the past," he said. "Their actions over the coming weeks and months will surface whether or not they are committed to sound science, and policies founded on sound science."

Tillerson's comments came during an initial session that lasted more than six hours. The hearing often centred on the US relationship with a resurgent Russia, which US intelligence agencies say worked to interfere with the US election on behalf of Trump.

The international agreement to limit Iran's nuclear programme came up only briefly. Tillerson stopped short of criticizing the deal which Trump has done - but said that he would conduct a full review of the pact. "The current agreement does freeze their ability to progress," Tillerson said of Iran, "but it does not ultimately deny them the ability to have a nuclear weapon."

That is not enough, he told senators. "What comes at the end of this agreement must be a mechanism that does in fact deny Iran the ability to develop a nuclear weapon."

Nature | doi:10.1038/nature.2017.21291 